\title{
Influence of Irrigation Levels and Row Spacings on Yield and Yield Attributing Characters of Mungbean Varieties (Vigna radiata L.) in Middle Gujarat Agro-climatic Zone
}

\author{
B.I. Karande ${ }^{*}$, H.R. Patel, D.D. Patil, S.B. Yadav and M.J. Vasani \\ Department of Agricultural Meteorology, B. A. College of Agriculture, \\ Anand Agricultural University, Anand, India \\ *Corresponding author
}

\begin{tabular}{|c|c|}
\hline & A B S T R A C T \\
\hline $\begin{array}{l}\text { Ke y w o r d s } \\
\text { Irrigation level, } \\
\text { Summer mungbean, } \\
\text { Row spacing, etc }\end{array}$ & \multirow{3}{*}{ 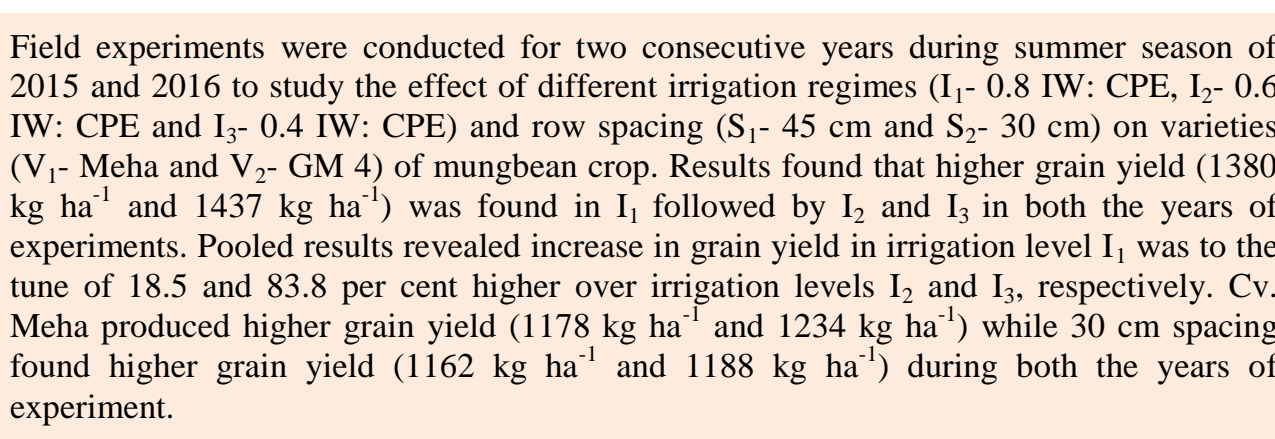 } \\
\hline Article Info & \\
\hline $\begin{array}{l}\text { Accepted: } \\
\text { 07 January } 2019 \\
\text { Available Online: } \\
10 \text { February } 2019\end{array}$ & \\
\hline
\end{tabular}

\section{Introduction}

Mungbean (Vigna radiata L.) is an important pulse crop and short duration grain legume with wide adaptability, low input requirement and have the ability to improve soil fertility by fixing atmospheric nitrogen. Mungbean is a native of India and Central Asia (Vavilov, 1926). In India, mungbean is grown on about 3.70 million hectares with annual production of 1.57 million tons. India is the largest producer of mungbean and account 54 per cent of the world production and covers $65 \%$ of the world acreage. In Gujarat, pulse crops grown on 7.0 lac ha out of which mungbean occupies more than 2.5 lac ha area with average kharif productivity of about 500 to $600 \mathrm{~kg} \mathrm{ha}^{-1}$.

Moisture stress during crop growth plays important role in productivity of mungbean. During summer season mungbean is cultivated under irrigated condition. Soil moisture stress causes increase in leaf and canopy temperature resulted in drying of leaves during vegetative stage resulted in poor and slow vegetative growth. While moisture stress at the reproductive stage of cropping season cause drying of leaves, flower abortion and dropping which leads to forced maturity 
with poor biomass and grain yield. If crops are exposed to soil moisture stress reducing grain yields more than $50 \%$.The summer mungbean productivity is 1000 to $1200 \mathrm{~kg}$ $\mathrm{ha}^{-1}$. During summer season, productivity of mungbean is low due to improper irrigation management and injudicious use of available water. It ranks second to drought resistance after soybean (Ali et al., 2001). On an average, it fixes atmospheric nitrogen @ 300 $\mathrm{kg} \mathrm{ha}^{-1}$ annually (Sharar et al., 2001). The nutritive value of mungbean lies in its high and easily digestible protein and contains approximately $25-28$ per cent protein, 1.0 per cent oil, 3.5-4.5 per centfibre, 4.5-5.5 per cent ash and 62-65 per cent carbohydrates on dry weight basis. New released varieties with optimum water supply as per the water requirement of variety and optimum plant population can give productivity of 1400 to $1600 \mathrm{~kg} \mathrm{ha}^{-1}$.

\section{Materials and Methods}

The experiment was laid out at Agronomy Farm, B. A. College of Agriculture, Anand Agricultural University, Anand, Gujarat during summer seasons of 2015 and 2016 in split plot design with irrigation levels as main plot $\left(\mathrm{I}_{1}-0.8 \mathrm{IW}\right.$ : CPE, $\mathrm{I}_{2}-0.6 \mathrm{IW}$ : $\mathrm{CPE}$ and $\mathrm{I}_{3}$ 0.4 IW: CPE), spacing $\left(\mathrm{S}_{1}: 45 \mathrm{~cm}\right.$ and $\mathrm{S}_{2}: 30$ $\mathrm{cm})$ and variety $\left(\mathrm{V}_{1}\right.$ : Meha and $\mathrm{V}_{2}$ : GM 4$)$ as sub plot treatments. The soil type of the experimental site is sandy loam a true representative soil of the region. Recommended agronomic practices were followed to raise the crop. The cumulative pan evaporation values were calculated from daily pan evaporation measured with the help of USWB class 'A' open pan evaporimeter installed at meteorological observatory, which was in the proximity of the experimental plot. The quantity of irrigation water applied in surface flooding was measured by $7.5 \mathrm{~cm}$ head Parshall flume. Yield and yield attributes observations were taken from 10 selected plants from each plot. Grain and biological yields were recorded from individual plots and expressed in $\mathrm{kg} \mathrm{ha}^{-1}$.

\section{Results and Discussion}

\section{Number of pods plant $^{-1}$}

The results presented in Table 1 indicated that irrigation regimes exerted significant effect on average number of pods plant ${ }^{-1}$. Irrigation level $\mathrm{I}_{1} \quad(0.8$ IW: $\mathrm{CPE}$ ratio) recorded significantly higher (20.10) average number of pods plant ${ }^{-1}$ which was found to be at par with irrigation levels $\mathrm{I}_{2}$ (0.6 IW: CPE ratio) in 2015, 2016 and pooled results. Significantly the lowest (15.87) average number of pods plant $^{-1}$ was observed with irrigation level $\mathrm{I}_{3}$ (0.4 IW: CPE ratio). This might be due to increase in number of irrigation at shorter intervals and total consumptive use of water. This situation avoided moisture stress and thus, provided very favourable conditions for moisture and nutrient availability. These results are in accordance with results those of Tank et al., (1992), Arya and Sharma (1994), Trivedi et al., (1994), Vijayalakshmi and Rajagopal (1995), Dabhi et al., (2000), Idnani and Gautam (2008) and Patel et al., (2016). An appraisal of data presented in Table 1 showed that the variety Meha $\left(\mathrm{V}_{1}\right)$ recorded significantly higher number of pods per plant than variety GM-4 $\left(\mathrm{V}_{2}\right)$ in 2016, 2017 and pooled results. Present results are in accordance with the results reported by Chovatia et al., (1993) and Tekale et al., (2011) for different varieties of green gram crop.

The differences due to row spacing were observed in number of pods per plant. The treatment $45 \mathrm{~cm}$ row spacing $\left(\mathrm{S}_{1}\right)$ recorded significantly higher pods per plant (19.70) compared to $30 \mathrm{~cm}$ row spacing in both the years as well as in pooled analysis. The results had good agreement with the results of 
Shukla and Dixit (1996) in green gram crop. Interaction effect between irrigation regimes, variety and row spacing on average number of pods plant ${ }^{-1}$ recorded at harvest of mungbean was found to be non-significant in both the years as well as pooled results (Table 1).

\section{Seed weight plant ${ }^{-1}$}

The results revealed that irrigation regimes had significant effect on average seed weight plant $^{-1}$. Irrigation level $\mathrm{I}_{1}(0.8 \mathrm{IW}$ : CPE ratio) recorded significantly the highest $(5.31 \mathrm{~g}$ plant $\left.^{-1}\right)$ average seed weight over irrigation levels $\mathrm{I}_{2}$ (0.6 IW: CPE ratio) and $\mathrm{I}_{3}$ (0.4 IW: $\mathrm{CPE}$ ratio) in both years as well as in pooled results. Significantly the lowest (2.96) average seed weight plant $^{-1}$ was observed with irrigation level $\mathrm{I}_{3}$ (0.4 IW: CPE ratio) in year 2015, 2016 and pooled results, while the variety Meha $\left(\mathrm{V}_{1}\right)$ recorded significantly higher seed weight per plant than variety GM$4\left(\mathrm{~V}_{2}\right)$ in 2015, 2016 and pooled results. The differences due to row spacing were observed in seed weight per plant. The treatment $45 \mathrm{~cm}$ row spacing $\left(\mathrm{S}_{1}\right)$ recorded significantly higher seed weight per plant (4.89) compared to 30 $\mathrm{cm}$ row spacing in both the years as well as in pooled analysis.

Interaction effect between irrigation regimes, variety and row spacing on average seed weight per plant recorded at harvest of mungbean was found to be non-significant in both the years as well as pooled results (Table $1)$.

\section{Test weight}

Data given in Table 1 revealed that the differences in test weight of mungbean were significantly affected due to irrigation regimes. Irrigation level $\mathrm{I}_{1}(0.8 \mathrm{IW}$ : $\mathrm{CPE}$ ratio) recorded significantly the highest $(38.05 \mathrm{~g})$ test weight of mungbean, in pooled analysis. Which was remained at par with irrigation levels $\mathrm{I}_{2}(0.6 \mathrm{IW}$ : CPE ratio) in year 2016. The lowest $(31.25 \mathrm{~g})$ test weight of mungbean was obtained in irrigation level $\mathrm{I}_{3}$ (0.4 IW: CPE ratio) in year 2015, 2016 and pooled results. This might be due to the severe water stress committed when the IW: CPE ratio become narrow. Water deficit during pod filling stage might have contributed towards the shrivelled seed. Further, continuous pod formation and excessive growth might have reduced the size of seed.

The results are in good conformity with those by Prasad and Yadav (1990), Arvadiya (1992) Dabhi et al., (2000) and Patel et al., (2016).The data presented in Table 1 indicated that the variety GM-4 $\left(\mathrm{V}_{2}\right)$ recorded significantly higher test weight than variety Meha $\left(\mathrm{V}_{1}\right)$ in year 2015, 2016 and pooled analysis. This was due to GM-4 was genetically bold seeded variety and size was larger than Meha variety. The differences due to row spacing were observed in test weight. The treatment $45 \mathrm{~cm}$ row spacing $\left(\mathrm{S}_{1}\right)$ recorded significantly higher test weight as compared to $30 \mathrm{~cm}$ row spacing $\left(\mathrm{S}_{2}\right)$ in both the years as well as in pooled analysis. This might be due to $45 \mathrm{~cm}$ row spacing caused lower plant population per unit area provided more moisture and nutrients to less number of grains resulted in more test weight compared to $30 \mathrm{~cm}$ row spacing. Similar results were reported by Rasul et al., (2012).

Interaction effect as presented in Table 2 revealed that the interaction between irrigation regimes and variety for test weight recorded at harvest of mungbean was found to be significant in year 2015 as well as pooled results. However, interactions were found non-significant during year 2016. The treatment combination $\mathrm{I}_{1} \mathrm{~V}_{2}$ produced significantly the highest test weight whereas the lowest was registered under treatment $\mathrm{I}_{3} \mathrm{~V}_{1}$ in year 2015 as well as poled results. 


\section{Seed yield}

Data pertaining to seed yield in $\mathrm{kg} \mathrm{ha}^{-1}$ as influenced by the different irrigation regimes, varieties and row spacing are presented in Table 3.

An appraisal of data in the table indicated that the grain yields were significantly affected by different irrigation regimes during 2015 and 2016 as well as in the pooled results. The treatment $\mathrm{I}_{1} \quad(0.8$ IW: $\mathrm{CPE}$ ratio $)$ was statistically superior $\left(1408 \mathrm{~kg} \mathrm{ha}^{-1}\right)$ over $\mathrm{I}_{2}$ and $\mathrm{I}_{3}$ treatments in both years and pooled results. Treatment $\mathrm{I}_{2}$ (0.6 IW: CPE ratio) recorded significantly higher grain yield over $\mathrm{I}_{3}$ (0.6 IW: CPE ratio) in both years and pooled results. The increase in seed yield in irrigation level $\mathrm{I}_{1}$ (0.8 IW: CPE ratio) was to the tune of 18.5 and 83.8 per cent higher over irrigation levels $\mathrm{I}_{2}$ (0.6 IW: CPE ratio) and $\mathrm{I}_{3}$ (0.4 IW: CPE ratio), respectively. The increase in seed yield with irrigation level $\mathrm{I}_{1}$ (0.8 IW: CPE ratio) might be due to increase in growth and yield attributes and also increase in irrigation frequency and total amount of water on account of increased ratio. Thus, there was progressive increase in seed yield due to favourable moisture condition and better availability of soil moisture at higher frequency of irrigation throughout the growth period which remarkably stimulated the yield attributing characters such as number of pods plant ${ }^{-1}$, number of seeds $\operatorname{pod}^{-1}$ and test weight. Another reason may be due to adequate supply of moisture favorably improved nutrient uptake and translocation which ultimately linked with growth and development. Beneficial effects of these parameters resulted in higher seed yield. The lowest seed yield $\left(766 \mathrm{~kg} \mathrm{ha}^{-1}\right)$ with irrigation level $\mathrm{I}_{3}$ (0.4 IW: CPE ratio) might be due to unsaturated soil moisture environment, a vapour gap would formed around the roots by their turgor pressure under water stress. Such a gap if ever present would reduce the availability of nutrients to the roots probably due to lesser contact between roots and water particle causing drastic reduction in dry matter production and uptake of nutrients. This might be the major reason for lower yield of crop with high moisture stress. The results are in close agreement with those reported by Vasimalai and Subramanian (1980), Prasad et al., (1990), Arvadiya (1992), Tank et al., (1992), Trivedi et al., (1994), Shukla and Dixit (1996), Dabhi et al., (2000), Bhadoria and Bhadoria (2002), Mitra and Bhattacharya (2005), Kumbhar et al., (2005), Idnani and Gautam (2008), Rasul et al., (2012), Mukesh Kumar (2016), Patel et al., (2016) and Bhardwaj and Hamama (2016).

The differences in the yield were also observed in the different varieties in both the years under study as well as in pooled results. The results showed that variety Meha $\left(\mathrm{V}_{1}\right)$ produced significantly higher grain yield $\left(1206 \mathrm{~kg} \mathrm{ha}^{-1}\right)$ over variety GM-4 in both the years as well as in pooled data. The per cent increase in seed yield by Meha was 14.64 per cent higher over GM-4 variety. The reason for higher grain yield in Meha variety might be due to the attribution of their resistance to yellow vain mosaic disease and ability to escape water stressed condition during the reproductive stage and adopted slow early growth and later vigorous growth resulted in high seed yield. This is due to cumulative effect of improvement in growth and yield attributes such as number of pods per plant (Table 1), number of seeds per pod (Table 3) and seed weight per plant (Table 3). These findings in the present investigation are in accordance with the findings of Faroda et al., (1983), Chovatia et al., (1993) and Tekale et al., (2009) for the greengram. The results presented in Table 2 indicated significant variations on seed yield by different spacing. Treatment $30 \mathrm{~cm}$ row spacing $\left(S_{2}\right)$ produced 
significantly higher seed yield (1175 kg ha $\left.{ }^{-1}\right)$ over $45 \mathrm{~cm}$ row to row spacing $\left(S_{1}\right)$ in both the years and pooled results. This might be due to higher leaf area produced under $30 \mathrm{~cm}$ spacing then $45 \mathrm{~cm}$ spacing in both the years. The consequence of higher vegetative biomass production and thereafter their partitioning in the seed yield production. The findings of the present investigation are similar to those reported by Rasul et al., (2012). These results are in close agreement with the findings of Singh and Yadav (1994) and Mitra and Bhattacharya (2005).

The interaction effects revealed that I X S interaction effect was found significant in year 2016 and pooled results. The treatment combination $\mathrm{I}_{1} \mathrm{~S}_{2}$ produced significantly the highest seed yield whereas the lowest was registered under treatment combinations of $\mathrm{I}_{3} \mathrm{~S}_{2}$.

\section{Straw yield}

Data pertaining to straw yield in $\mathrm{kg} \mathrm{ha}^{-1}$ as influenced by the different irrigation regimes, varieties and row spacing are presented in Table 3 The significant differences in the biomass yields were observed in the different irrigation regimes, varieties and row spacings in both the 2015 and 2016 years as well as in pooled results.

The data revealed that the treatment $I_{1}(0.8$ IW: CPE ratio) was found statistically superior $\left(2468 \mathrm{~kg} \mathrm{ha}^{-1}\right)$ over $\mathrm{I}_{2}$ (0.6 IW: CPE ratio) and $\mathrm{I}_{3}$ (0.4 IW: CPE ratio) treatments in year 2015 and pooled results. Treatment $\mathrm{I}_{2}$ (0.6 IW: CPE ratio) recorded significantly higher straw yield over $\mathrm{I}_{3}(0.4 \mathrm{IW}$ : CPE ratio) treatment in year 2015, 2016 and pooled results. In year 2016 treatment $\mathrm{I}_{1}(0.8 \mathrm{IW}$ : $\mathrm{CPE}$ ratio) and $\mathrm{I}_{2}$ (0.6 IW: CPE ratio) were at par and both were significantly superior over treatment $\mathrm{I}_{3}(0.4 \mathrm{IW}$ : CPE ratio). The reason might be due to the optimum utilization of soil moisture and nutrients which have contributed in increasing leaf area and biomass which ultimately resulted in accumulation more biomass yield under $I_{1}$ and $I_{2}$ treatments. This might be due to adequate moisture supply throughout the entire growth period which resulted in to better growth and development. The lowest $\left(1721 \mathrm{~kg} \mathrm{ha}^{-1}\right)$ straw yield was recorded with irrigation level $\mathrm{I}_{3}$ (0.4 IW: CPE ratio). A remarkable reduction in straw yield with limited water supply was explained on the basis of internal water status in relation to different physiological processes taking place in the plant. The results are conformity with those reported by Prasad and Yadav (1990), Tank et al., (1992), Dabhi et al., (2000), Kumbhar et al., (2005), Idnani and Gautam (2008), Patel et al., (2016) and Mukesh et al., (2016). Water deficit affects every aspect of plant life and inhibits growth, development and productivity. The retardation of plant growth under water stress is attributed to reduced accumulation of dry biomass due to inhibition of physiological processes (Singh and Yadav, 2000).

The differences in the straw yield were observed in the different varieties in both the years as well as in pooled results. The results showed that variety Meha $\left(\mathrm{V}_{1}\right)$ produced significantly higher straw yield (2243 $\left.\mathrm{kg} \mathrm{ha}^{-1}\right)$ over variety GM-4 $\left(\mathrm{V}_{2}\right)$ in both the years as well as in pooled data. The per cent increase in straw yield by Meha was 7 per cent over the GM-4 variety in pooled results. The reason for higher grain yield in Meha variety might be due to the attribution of their resistance to yellow vain mosaic disease and ability to sustain water stressed condition. Meha showed slow early growth and later vigorous growth resulted in high biomass accumulation. These results are in close agreement with the findings of Chovatia et al., (1993) and Dhanga (2006) for mungbean crop. The significantly higher straw yield 
(2316 kg ha ${ }^{-1}$ ) was recorded under $30 \mathrm{~cm}$ spacing $\left(S_{2}\right)$ over $45 \mathrm{~cm}\left(S_{1}\right)$ row to row spacing in both years as well as in pooled results. This may be due to higher leaf area produced under $30 \mathrm{~cm}$ spacing then $45 \mathrm{~cm}$ spacing in the both years. The higher plant population resulted in more biomass accumulation. The research of the present investigation is similar to those reported by Rasul et al., (2012). These results are in close agreement with the findings of Mansoor et al., (2010).

The interaction effects as presented in Table 4 revealed that interaction effects were found non significant in 2015, 2016 and pooled results. These results are in close agreement with the findings of Chovatia et al., (1993) for green gram crop.

Table.1 Influence of irrigation levels and spacing on yield attributes of mungbean

\begin{tabular}{|c|c|c|c|c|c|c|c|c|c|}
\hline \multirow[t]{2}{*}{ Treatment } & \multicolumn{3}{|c|}{ Pods plant ${ }^{-1}$} & \multicolumn{3}{|c|}{ Seed weight plant ${ }^{-1}(\mathrm{~g})$} & \multicolumn{3}{|c|}{ Test weight (g) } \\
\hline & 2015 & 2016 & Pooled & 2015 & 2016 & Pooled & 2015 & 2016 & Pooled \\
\hline$I_{1}(0.8$ IW:CPE) & 20.1 & 20.2 & 20.1 & 4.91 & 5.71 & 5.31 & 37.25 & 38.84 & 38.04 \\
\hline$I_{2}(0.6$ IW:CPE) & 18.1 & 20.2 & 19.3 & 4.30 & 4.67 & 4.48 & 35.72 & 37.01 & 36.36 \\
\hline $\mathbf{I}_{3}$ (0.4 IW:CPE) & 15.2 & 16.5 & 15.9 & 2.94 & 2.99 & 2.96 & 32.15 & 30.36 & 31.25 \\
\hline S.Em. \pm & 0.64 & 0.45 & 0.38 & 0.10 & 0.15 & 0.09 & 0.37 & 0.51 & 0.44 \\
\hline CD at $5 \%$ & 2.50 & 1.75 & 1.26 & 0.38 & 0.60 & 0.29 & 1.47 & 2.00 & 1.45 \\
\hline CV \% & 12.39 & 8.10 & 10.33 & 8.23 & 11.83 & 10.38 & 3.70 & 4.97 & 4.39 \\
\hline $\mathrm{V}_{1}$ (Meha) & 18.7 & 20.1 & 19.3 & 4.31 & 4.59 & 4.44 & 32.13 & 30.20 & 31.16 \\
\hline$V_{2}(G M-4)$ & 16.8 & 18.1 & 17.4 & 3.79 & 4.33 & 4.06 & 37.96 & 40.61 & 39.28 \\
\hline 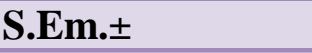 & 10.39 & 0.26 & 0.23 & 0.08 & 0.08 & 0.05 & 0.29 & 0.29 & 0.58 \\
\hline CD at $5 \%$ & 1.15 & 0.76 & 0.66 & 0.24 & 0.25 & 0.16 & 0.86 & 0.86 & 1.83 \\
\hline$S_{1}(45 \mathrm{~cm})$ & 18.9 & 20.4 & 19.7 & 4.66 & 5.14 & 4.89 & 36.42 & 36.57 & 36.49 \\
\hline$S_{2}(30 \mathrm{~cm})$ & 16.5 & 17.7 & 17.1 & 3.44 & 3.78 & 3.61 & 33.66 & 34.24 & 33.95 \\
\hline S.Em.. & 0.39 & 0.26 & 0.23 & 0.08 & 0.08 & 0.05 & 0.29 & 0.29 & 0.50 \\
\hline CD at $5 \%$ & 1.15 & 0.76 & 0.66 & 0.24 & 0.25 & 0.16 & 0.86 & 0.86 & 1.43 \\
\hline CV \% & 9.24 & 5.60 & 7.55 & 8.31 & 8.01 & 8.15 & 3.48 & 3.47 & 3.48 \\
\hline Interaction table & NS & NS & NS & NS & NS & NS & I x V & NS & $\mathrm{I} \times \mathrm{V}$ \\
\hline
\end{tabular}

Table.2 Interaction effects on test weight between irrigation levels and variety (I x V) of Mungbean

\begin{tabular}{|c|c|c|c|c|}
\hline \multirow[t]{3}{*}{ Treatment } & \multicolumn{4}{|c|}{ Test weight } \\
\hline & \multicolumn{2}{|c|}{2015} & \multicolumn{2}{|c|}{ Pooled } \\
\hline & $\begin{array}{c}\mathbf{V}_{1} \\
\text { (Meha) }\end{array}$ & $\begin{array}{c}\mathbf{V}_{2} \\
(\mathbf{G M}-4)\end{array}$ & $\begin{array}{c}\mathbf{V}_{1} \\
\text { (Meha) }\end{array}$ & $\begin{array}{c}\mathbf{V}_{\mathbf{2}} \\
(\mathbf{G M}-\mathbf{4})\end{array}$ \\
\hline $\mathrm{I}_{1}(0.8 \mathrm{IW}: \mathrm{CPE})$ & 34.19 & 40.31 & 34.06 & 42.03 \\
\hline $\mathrm{I}_{2}(0.6 \mathrm{IW}: \mathrm{CPE})$ & 31.73 & 39.70 & 31.70 & 41.02 \\
\hline $\mathrm{I}_{3}(0.4 \mathrm{IW}: \mathrm{CPE})$ & 30.45 & 33.85 & 27.72 & 34.79 \\
\hline S.Em. \pm & \multicolumn{2}{|c|}{0.41} & \multicolumn{2}{|c|}{0.501} \\
\hline CD at $5 \%$ & \multicolumn{2}{|c|}{1.21} & \multicolumn{2}{|c|}{1.43} \\
\hline
\end{tabular}


Table.3 Influence of irrigation levels and spacing on yield of mungbean

\begin{tabular}{|c|c|c|c|c|c|c|c|c|c|}
\hline \multirow[t]{2}{*}{ Treatment } & \multicolumn{3}{|c|}{ Seed yield $\left(\mathrm{kg} \mathrm{ha}^{-1}\right)$} & \multicolumn{3}{|c|}{ Straw yield $\left(\mathrm{kg} \mathrm{ha}^{-1}\right)$} & \multicolumn{3}{|c|}{ Harvest index (\%) } \\
\hline & 2015 & 2016 & Pooled & 2015 & 2016 & Pooled & 2015 & 2016 & Pooled \\
\hline$I_{1}(0.8$ IW:CPE) & 1380 & 1437 & 1408 & 2325 & 2610 & 2468 & 37.2 & 35.5 & 36.3 \\
\hline$I_{2}(0.6$ IW:CPE) & 1128 & 1247 & 1188 & 2118 & 2504 & 2311 & 34.7 & 33.2 & 33.9 \\
\hline $\mathrm{I}_{3}(0.4 \mathrm{IW}: \mathrm{CPE})$ & 758 & 764 & 761 & 1565 & 1876 & 1721 & 33.0 & 29.8 & 31.4 \\
\hline S.Em. \pm & 25.5 & 31.1 & 20.1 & 39.8 & 61.8 & 37.7 & 0.49 & 0.48 & 0.63 \\
\hline CD at $5 \%$ & 100.1 & 122.3 & 62.4 & 156.3 & 192.6 & 120.0 & 1.93 & 1.88 & 2.07 \\
\hline CV \% & 8.4 & 9.3 & 8.9 & 8.3 & 10.8 & 9.9 & 4.39 & 4.56 & 4.47 \\
\hline$V_{1}$ (Meha) & 1178 & 1234 & 1206 & 2058 & 2428 & 2243 & 35.3 & 33.4 & 34.3 \\
\hline $\mathrm{V}_{2}(\mathrm{GM}-4)$ & 1038 & 1065 & 1052 & 1914 & 2299 & 2106 & 33.9 & 31.0 & 32.4 \\
\hline S.Em. \pm & 20.3 & 17.7 & 13.4 & 29.7 & 28.2 & 20.6 & 0.44 & 0.44 & 0.31 \\
\hline CD at $5 \%$ & 60.4 & 52.6 & 38.6 & 88.5 & 84.5 & 59.1 & 1.32 & 1.32 & 0.90 \\
\hline$S_{1}(45 \mathrm{~cm})$ & 1054 & 1111 & 1082 & 1924 & 2341 & 2122 & 35.4 & 32.8 & 34.1 \\
\hline $\mathrm{S}_{2}(30 \mathrm{~cm})$ & 1162 & 1188 & 1175 & 2146 & 2486 & 2316 & 33.7 & 31.6 & 32.7 \\
\hline S.Em. \pm & 20.3 & 17.7 & 13.4 & 29.7 & 28.2 & 20.6 & 0.44 & 0.44 & 0.31 \\
\hline CD at $5 \%$ & 60.4 & 52.6 & 38.6 & 88.5 & 84.5 & 59.1 & 1.32 & NS & 0.90 \\
\hline CV \% & 8.1 & 6.5 & 7.3 & 7.63 & 6.13 & 6.81 & 4.84 & 5.16 & 5.00 \\
\hline Interaction table & Ix S & Ix $S$ & I x S & NS & NS & NS & I x S & Ix S & Ix S \\
\hline
\end{tabular}

Table.4 Interaction effects on seed yield between irrigation levels and row spacing (I x S) of mungbean

\begin{tabular}{|c|c|c|c|c|}
\hline \multirow[t]{3}{*}{ Treatment } & \multicolumn{4}{|c|}{ Seed yield $\left(\mathrm{kg} \mathrm{ha}^{-1}\right)$} \\
\hline & \multicolumn{2}{|c|}{2016} & \multicolumn{2}{|c|}{2016} \\
\hline & $\begin{array}{c}S_{1} \\
(45 \mathrm{~cm})\end{array}$ & $\begin{array}{c}S_{1} \\
(45 \mathrm{~cm})\end{array}$ & $\begin{array}{c}S_{1} \\
(45 \mathrm{~cm})\end{array}$ & $\begin{array}{c}S_{1} \\
(45 \mathrm{~cm})\end{array}$ \\
\hline$I_{1}(0.8$ IW:CPE) & 1346 & 1527 & 1335 & 1482 \\
\hline$I_{2}(0.6$ IW:CPE) & 1206 & 1288 & 1127 & 1249 \\
\hline $\mathrm{I}_{3}(0.4 \mathrm{IW}: \mathrm{CPE})$ & 781 & 748 & 770 & 761 \\
\hline S.Em. \pm & \multicolumn{2}{|c|}{30.6} & \multicolumn{2}{|c|}{23.3} \\
\hline CD at $5 \%$ & \multicolumn{2}{|c|}{91.1} & \multicolumn{2}{|c|}{67.0} \\
\hline
\end{tabular}

Table.5 Interaction effects on harvest index irrigation levels and row spacing (I x S) of Mungbean

\begin{tabular}{|c|c|c|c|c|}
\hline \multirow[t]{3}{*}{ Treatment } & \multicolumn{4}{|c|}{ Harvest index (\%) } \\
\hline & \multicolumn{2}{|c|}{2015} & \multicolumn{2}{|c|}{2015} \\
\hline & $\begin{array}{c}S_{1} \\
(45 \mathrm{~cm})\end{array}$ & $\begin{array}{c}S_{1} \\
(45 \mathrm{~cm})\end{array}$ & $\begin{array}{c}S_{1} \\
(45 \mathrm{~cm})\end{array}$ & $\begin{array}{c}S_{1} \\
(45 \mathrm{~cm})\end{array}$ \\
\hline $\mathrm{I}_{1}(0.8$ IW:CPE) & 36.5 & 35.4 & 36.1 & 35.9 \\
\hline $\mathrm{I}_{2}(0.6$ IW:CPE) & 34.6 & 34.8 & 33.7 & 34.2 \\
\hline$I_{3}(0.4$ IW:CPE) & 35.0 & 31.1 & 32.6 & 29.9 \\
\hline S.Em. \pm & \multicolumn{2}{|c|}{0.57} & \multicolumn{2}{|c|}{0.54} \\
\hline CD at $5 \%$ & \multicolumn{2}{|c|}{1.70} & \multicolumn{2}{|c|}{1.55} \\
\hline
\end{tabular}




\section{Harvest index}

The treatment $\mathrm{I}_{1}$ (0.8 IW: CPE ratio) was significantly superior over $\mathrm{I}_{2}$ (0.6 IW: CPE ratio) and $\mathrm{I}_{3}(0.4 \mathrm{IW}$ : CPE ratio) treatments in year 2015, 2016 and pooled results. Treatment $\mathrm{I}_{2}$ recorded significantly higher harvest index in 2016 as well as in the pooled results, however, in $2015 \mathrm{I}_{2}$ and $\mathrm{I}_{3}$ treatments were found at par. The reason might be due to the lowest grain yield and excessive vegetative growth might have attributed towards decrease in harvest index. These findings are in agreement with Khade et al., 1986, Hossain et al., 2005, Akhter et al., 2007. Patel et al., (2016) also reported that stress during pod filling phase reduced pod initiation and pod growth rate and thereby reduced the harvest index (Table 3 ).

The results showed that variety Meha $\left(\mathrm{V}_{1}\right)$ recorded significantly superior harvest index over GM-4 $\left(\mathrm{V}_{2}\right)$ in both the years as well as in pooled data (Table 2). The reason might be due longer duration and higher growth rates produced higher seed yield resulted in higher harvest index by variety Meha.

The results presented in Table 5 indicated significant variations in harvest index by different row spacing. Treatment with $45 \mathrm{~cm}$ row spacing $\left(\mathrm{S}_{1}\right)$ recorded significantly higher harvest index over $30 \mathrm{~cm}\left(S_{2}\right)$ row to row spacing in both years and pooled results. This might be due to under $30 \mathrm{~cm}$ row spacing occupied higher plant population per unit area produced more straw yield under $30 \mathrm{~cm}$ row spacing then $45 \mathrm{~cm}$ row spacing in both the years and pooled results. The consequence of higher vegetative biomass production had reduced harvest index. The finding of the present investigation is similar to those reported by Mitra and Bhattacharya (2005), Mansoor et al., (2010) and Rasul et al., (2012).
The interaction effects as presented in Table 5 revealed that I X S interaction effect was found significant in year 2015 and pooled results. The treatment combination $\mathrm{I}_{1} \mathrm{~S}_{1}$ produced the highest harvest index while lowest recorded in $\mathrm{I}_{3} \mathrm{~S}_{2}$ it was at par with $\mathrm{I}_{1} \mathrm{~S}_{2}$ treatment in 2015 and pooled results. The lowest was registered under treatment combinations of $\mathrm{I}_{3} \mathrm{~S}_{2}$.

The present study concluded that irrigation at 0.8 IW: CPE ratio for mungbean exhibited significantly higher yield for both variety due to optimal soil moisture for various plant process. Between varieties, variety Maha produced significantly higher grain yield over variety GM-4. Between two row spacing, row spacing $30 \mathrm{~cm}$ exhibited higher seed yield due to higher leaf area production and biomass production resulted in higher yield the crop.

\section{References}

Ali, A., Nadeem, M. A., Tayyab, M., Tahir, M. and Sohail M. R. (2001). Determining suitable planting geometry for two mungbean (Vigna radiate L.) cultivars under Faisalabad conditions. Pakistan J. Biol. Sci. 4: 344-450.

Akhter, A., Hossain, K., Talukder, M. S. U., Sarkar, A. A. and Hye, M. A. (2007). Effect of irrigation at various growth stages on yield and water use of mungbean. Bangladesh J. Agril. Sci. 34 (1): 49-54.

Arvadia, L. K. (1992). Response of summer green gram (Vigna radiate L. Wilczek) to irrigation, weed management and varying levels of phosphorus. M.Sc. (Agri.) thesis submitted to G. A. U., Sardar Krushinagar. Bhadoria, R. B. S. and Bhadoria, H. S. (2002). Effect of irrigation on growth and yield of guar and moong under semi-arid 
conditions. Indian J. Soil. Cons., 30 (3): 46-48.

Bhardwaj, H. L. and Hamama, A. A. (2016). Cultivar, Planting Date and Row Spacing Effects on Mungbean Performance in Virginia. Hort. Sci. 51 (6):67-73.

Chovatia, P. K., Ahlawat, R. P. S. and Trivedi, S. J. (1993). Growth and yield of summer greengram (Phaseolus radiatus) as affected by different dates of sowing, Rhizobium inoculation and levels of phosphorous. Indian Journal of Agronomy 38(3): 492-494.

Dabhi, B. M., Solanki, R. M. and Patel, J. C. (2000). Response of summer green gram to irrigation systems based on IW/CPE ratio. Gujarat Agricultural University Research Journal, 25 (2):20-23

Dhanga, A. B. (2006). Effect of dates of sowing and spacing on growth, yield attributes and yield of rabigreen gram cv. CO-4 under middle Gujarat conditions. M. Sc. (Agri.) Thesis submitted to AAU, Anand. Hossain, M. K., Talukder, M. S. U. and Sarkar, A. A. (2005). Response of mungbean to irrigation. J. of Agric. Engineering, 32(A): 113-119.

Idnani, L. K. and Gautam, H. K. (2008). Water economization in summer greengram (Vigna radiata) as influenced by irrigation regimes and land configurations. Indian J. Agric. Sci., 78 (3): 214-219.

Mitra, S. and Bhattacharya, B. K. (2005). Water use and productivity of green gram (Vigna radiata var. radiata) as influenced by spacings, mulching and weed control under rainfed upland situation of Tripura. Indian J. Agril. Sci., 75 (1): 52-54.

Mukesh, K., PanwarG. S. and Sitaram, K. (2016). Effect of Planting Date, Grain Rate and Row Spacing on Nodulation
Efficiency of Bold Grained Spring Mung bean [Vigna radiata (L.) Wilczek] in Bundelkhand Region of India. Legume Res. 39 (2): 293-296.

Patel, A. P., Patel, D. B., Chaudhary, M. M., Parmar P. N. and Patel, H. K. (2016). Influence of Irrigation Scheduling Based on IW: CPE Ratio and Levels of Sulphur on Growth and Yieldof Rabi Greengram [Vigna radiate (L.) Mills]. J. Pure Appl. Microbiol., 10(1): 20-25.

Prasad, T. and Yadav, D. S. (1990). Effect of irrigation and plant density on yield attributes and yield of green gram and black gram. Indian J. Agron., 35 (1-2): 99-101.

Rasul, F., Cheema, F. A., Sattar, A., Saleem, M. F. And Washid, M. A. 2012. Evaluting the performance of three mungbean varieties grown under varying inter row spacing. $J$. of Animal and pl. Sci. 22(4):1030-1035.

Shukla, S. K. and Dixit, R. S. (1996). Effect of Rhizobium inoculation, plant population and phosphorus on growth and yield of summer green gram (Phaseolus radiatus). Indian. J. Agron. 41 (4): 611-615.

Singh, S. and Yadav, D. S. (1994). Response of summer black gram (Phaseolus mungo) to row spacing and seed rate. Indian J. Agron. 39 (2): 314-315.

Sharar, M. S., Ayub, M., Nadeem, M. A. and Noori, S. A. (2001). Effect of different row spacings and graining densities on the growth and yield of gram (Cicer arietinum L.). Department of Agronomy, University of Agriculture, Faisalabad, Pakistan. 38 (3-4): 51-53.

Tank, U. N., Damor, U. M., Patel, J. C. and Chauhan, D. S. (1992). Response of summer greengram (Phaseolus radiata) to irrigation, nitrogen and phosphorus. Indian J. Agron., 37(4): 833-835. 
Tekale, C. D., Patel, D. D., Dongare R. S. and Patil, S. D. (2011). Performance of greengram (Vigna radiata $\mathrm{L}$.) cultivars under different dates of sowing. Bioinfolet. 8 (4): 415-416.

Trivedi, S. J., Savalia, S. G., Ahlawat, R. P. S. and Patel D. U. (1994). Effect of irrigation schedules, depth of ploughing and mulches on growth and yield of summer green gram. Legume Res., 17 (2): 93-95

Vasimalai, M. P. and Subramanian, S. (1980).

Response of green gram to irrigation and phosphorus. Madras Agric. J., 67 (8): 506-509.

Vavilov, N. I. (1926). Studies on the origin of cultivated plants. Bull. Appl., 16: 139148.

Vijayalakshmi, R. and Rajagopal, A. (1995). Effects of irrigation levels and irrigation layouts on the yield attributes and grain yield of greengram. Madras Agric. J., 82 (4): 271-273.

\section{How to cite this article:}

Karande, B.I., H.R. Patel, D.D. Patil, S.B. Yadav and Vasani, M.J. 2019. Influence of Irrigation Levels and Row Spacings on Yield and Yield Attributing Characters of Mungbean Varieties (Vigna radiata L.) in Middle Gujarat Agro-climatic Zone. Int.J.Curr.Microbiol.App.Sci. 8(02): 464-473. doi: https://doi.org/10.20546/ijcmas.2019.802.052 